\title{
DEVELOPMENT OF THE INTANGIBLE CULTURAL HERITAGE IN THE CITY OF PORTO-NOVO: THE PLACE OF DANCE WITHIN TOURISM
}

\author{
Akogbeto Nadine B. ${ }^{1}$, Houenoude Didier ${ }^{2}$, VissinExpedit W. ${ }^{1}$ and Houssou Christophe S. $^{1}$ \\ ${ }^{1}$ Pierre PAGNEY Laboratory, Climate, Water, Ecosystems and Development (LACEEDE), University of Abomey- \\ Calavi (Benin) \\ ${ }^{2}$ Department of History and Archeology at Faculties of (FASHS) at the University of Abomey-Calavi, Benin
}

https://doi.org/10.35410/IJAEB.2020.5479

\begin{abstract}
The problems related to the enhancement of our intangible cultural heritage in general and our traditional dances in particular are enormous and constitute a shortfall for tourism in Benin localities: Porto-Novo including the capital. And yet the community lives in a specific cultural and natural environment that remains an important source of its socio-economic and cultural development. This study aims to highlight the importance of traditional dances, the expression of emotions, freedom and the joy of living and folklore for tourism and local development of the city.

The methodology adopted focuses on desk research and field surveys. Moreover, after the field work and counting, it appears that in Porto-Novo, several types of traditional dances are practiced grouping the "adjogan", the "djègbé", the "zinlin", the "kpanouhoun", the "Massègohoun", the "kaka", the "ogbon" and the "èyo". But tourists visiting the capital are hardly met in cultural venues that highlight traditional dances due to lack of communication.

Finally, for the development of traditional dances by tourism in Porto-Novo, activities related to: traditional dance competitions, voodoo festivals, festivals, training of young people on traditional dances, initiation of children to dances schools and the creation of traditional dance training centers should therefore be promoted.
\end{abstract}

Keywords: Porto-Novo; traditional dance; intangible cultural heritage; development; tourism.

\section{INTRODUCTION}

As a major provider of jobs and income, tourism allows a significant number of job seekers to find work and access a non-negligible level of income (Amore, 2014; Vellas, 2004). Consequently, it contributes to poverty reduction in developing countries (UNWTO, 2004, 2011). But all of this presupposes the enhancement of the natural assets and the tangible and intangible heritage of the tourist destination (Gantheil2002; Principaud, 2001; TchaouHodonou, 2001). 
In Benin, intangible cultural heritage is not valued, which is a blow to the development of Beninese tourism and at the same time to the development of the city (Elègbè, 2001; KABO SIOUEME, 2007). In terms of intangible cultural heritage in Benin, traditional dances occupy one of the first places. This means that there can be no tourism development without the enhancement of heritage (Mehou-loko, 1976; MCAT / DPPT, 2007; Dekounhon, 2016).

The problem of using traditional dances in the development of tourism therefore arises acutely in all the cities of the country and in particular in that of Porto-Novo. This is a real problem to be solved in the sense that little importance is given to traditional dances (Akogbéto, 2016).

The objective of this work is to highlight the importance of traditional dances in the local development of the city of Porto-Novo through tourism.

Porto-Novo, the administrative capital of Benin is located $30 \mathrm{~km}$ from Cotonou. In the Ouémé department, it is located between $2^{\circ} 34$ 'and $2^{\circ} 40^{\prime}$ east longitude and $6^{\circ} 30$ 'north latitude and 6 ${ }^{\circ} 26$ 'north latitude. With an area of $52 \mathrm{~km}^{2}$ or $0.05 \%$ of the national territory (INSAE, 2004), it is limited in the North by the Communes of Akpro-Missérété, Avrankou and Adjarra; in the South by the Municipality of Sèmè- kpodji; to the East by the Municipality of Adjarra; to the West by the Commune of Aguégués (figure 1). 
Vol. 5, No. 01; 2020

ISSN: $2456-8643$

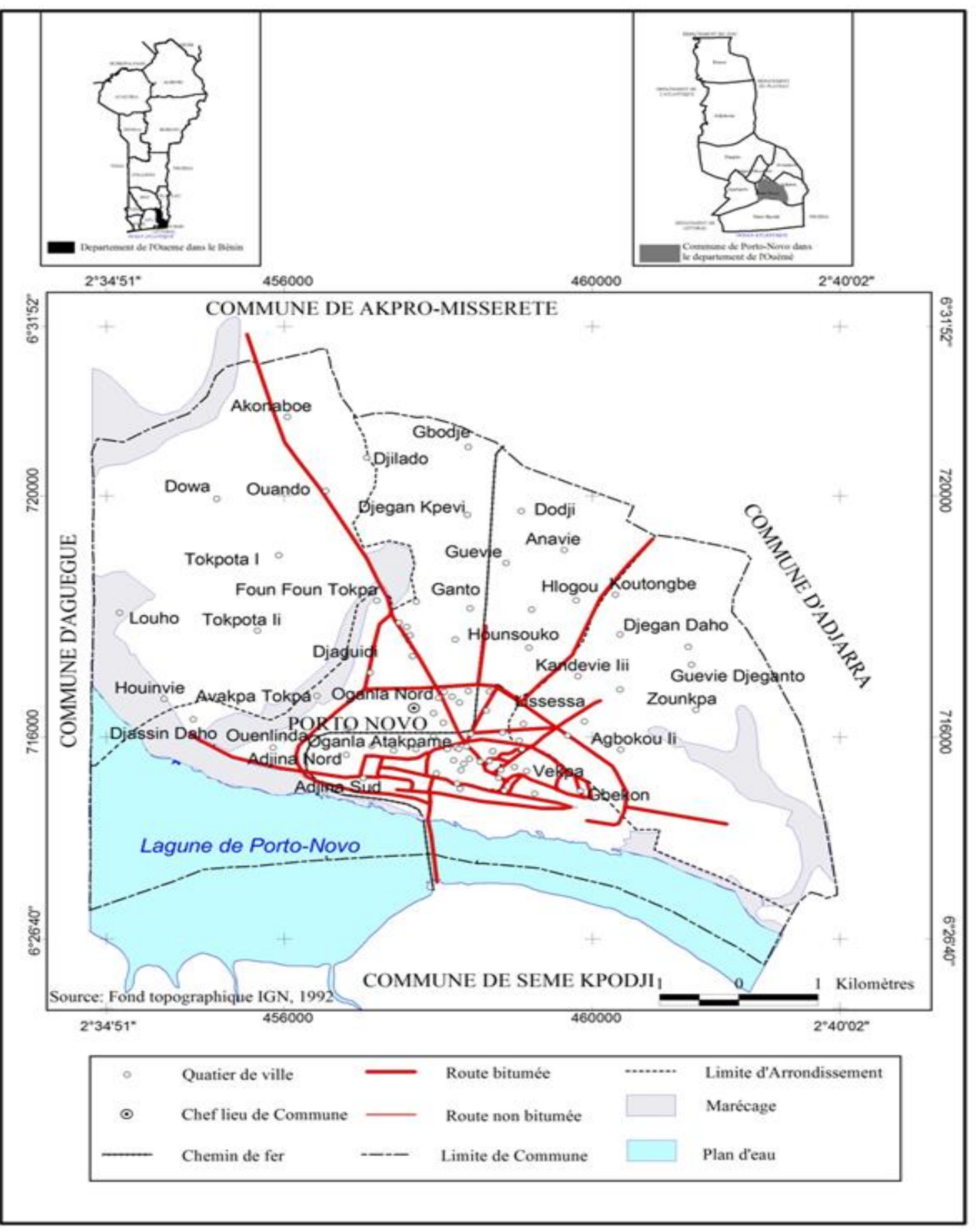

Figure 1: Geographical location of the city of Porto-Novo

\section{RESEARCH METHODOLOGY}


The adopted methodology consisted first of all in a literature review on the issue of the enhancement of heritage in Benin and then in carrying out in-depth interviews in the direction of the socio-professional categories concerned by the research subject.

\subsection{Type of data collection}

It is a collection of data based on in-depth surveys carried out using the collection tools that are interview guides, questionnaires and observation grids on research sites. It made it possible not only to identify practices in promoting traditional dances in the city of Porto-Novo but also to identify the determinants that justify the failure of these practices.

\subsection{Sampling technique and size}

Since research is essentially qualitative in nature, the sampling technique used is that of the reasoned choice of actors. The basic population considered is that of all the actors concerned by the question of tourism and more precisely of the intangible cultural heritage in the national, departmental, communal and family spheres of Benin. These are actors from ministries, NGOs, municipal and local elected officials, travel agencies and tourists. Thus, in an inductive approach, the 110 actors are selected in the city of Porto-Novo according to the involvement in tourism and heritage management.

The table below presents the statistical distribution of the different social categories interviewed.

Table I: Sample size

\begin{tabular}{|c|l|l|}
\hline $\mathbf{N}^{\circ}$ & \multicolumn{1}{|c|}{ STRUCTURES } & \multicolumn{1}{|c|}{ NOMBRE } \\
\hline 01 & Tourist Office & 04 \\
\hline 02 & Travel agency & 05 \\
\hline 03 & National Archives & 05 \\
\hline 04 & National Library & 06 \\
\hline 05 & African Heritage School & 06 \\
\hline 06 & Da silva museum & 04 \\
\hline 07 & Ethnographic Museum & 04 \\
\hline 08 & Honmè Museum & 04 \\
\hline 09 & Garden of Plants and Nature & 02 \\
\hline 10 & hotels & 06 \\
\hline 11 & Cultural Heritage Department of Porto-Novo & 04 \\
\hline 12 & tourists & 60 \\
\hline & Total & $\mathbf{1 1 0}$ \\
\hline
\end{tabular}

Total 110

Source: Survey results, December 2014 


\subsection{Data processing and analysis of results}

The data collected has been classified by theme and center of interest, analyzed and processed manually, then subscribed to a descriptive and analytical analysis. The results of this research revolve around several points.

\section{RESULTS AND DISCUSSION}

The populations of the city of Porto-Novo practice several types of traditional dances which are: the "adjogan", the "djègbé", the "zinlin", the "kpanouhoun", the "massègohoun", the "kaka", the " ogbon "," èyo ", etc. only a few of which are typically from Porto-Novo.

Figure 2 shows the types of traditional dances practiced by the populations of Porto-Novo.

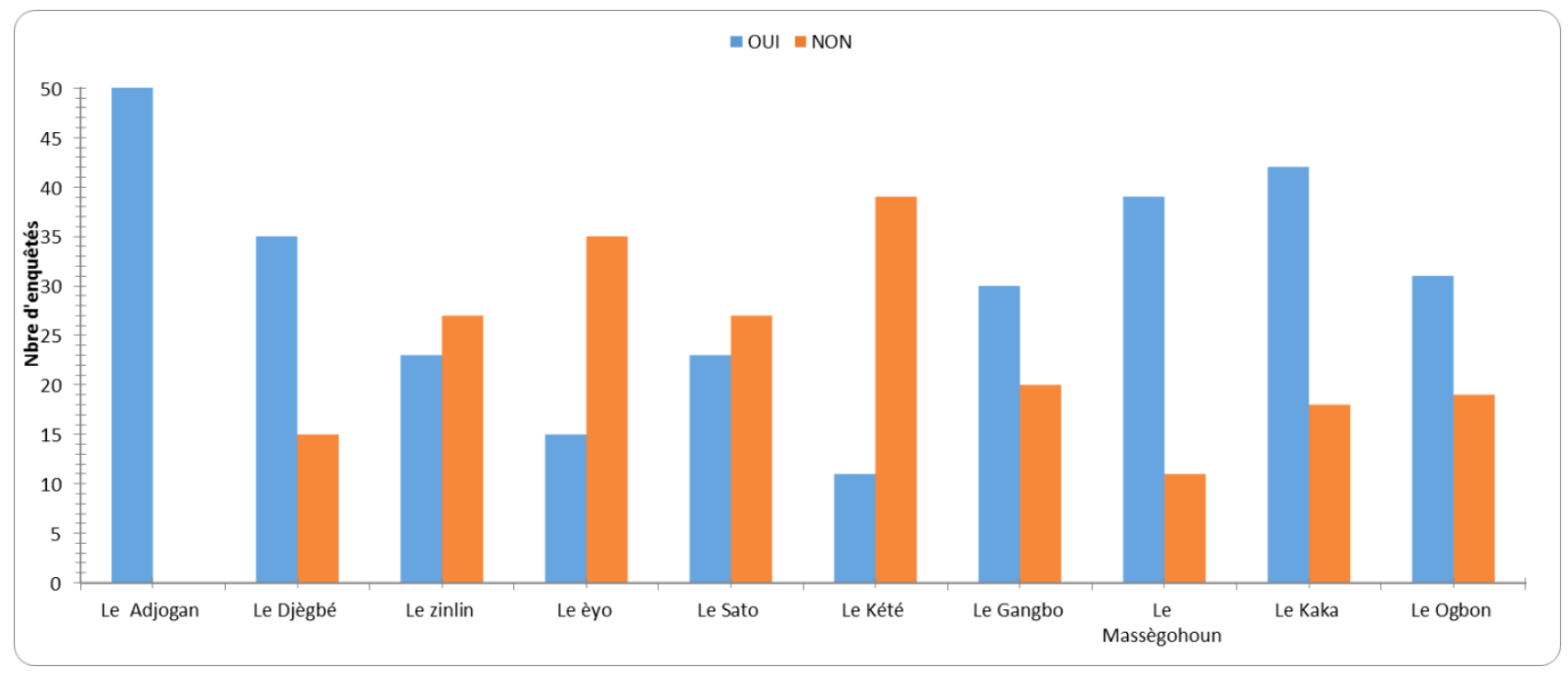

Figure 2: Types of traditional dances existing in Porto-Novo

Source: Field survey, December 2014

Analysis of the graph shows that the types of traditional dances best known by the populations are, in order, "Adjogan", "Kaka", "Massègohoun", "Djègbè", and "Ogbon" . The types of traditional dance least known by the populations surveyed are "Kété" and "Eyo". The Gangbo, Zinli and Sato dances are known by at least half of the population surveyed. The knowledge of these types of dances by the populations would be explained by the fact that these dances are from the territory of Porto-Novo. On the other hand, the dances less known by the populations can be explained by the fact that these dances come from surrounding or distant localities.

\subsection{Traditional dances of the city of Porto-Novo}

The traditional dances of the city of Porto-Novo are adjogan, djègbé, Zinlin, eyo, sato, kpanouhoun, Massè-Gohoun, kaka, ogbon, zangbéto and ddance desEgun-gun. 


\section{The adjogan:}

Photo 1 illustrates a group of women performing the traditional dance steps of adj " Adogan '.

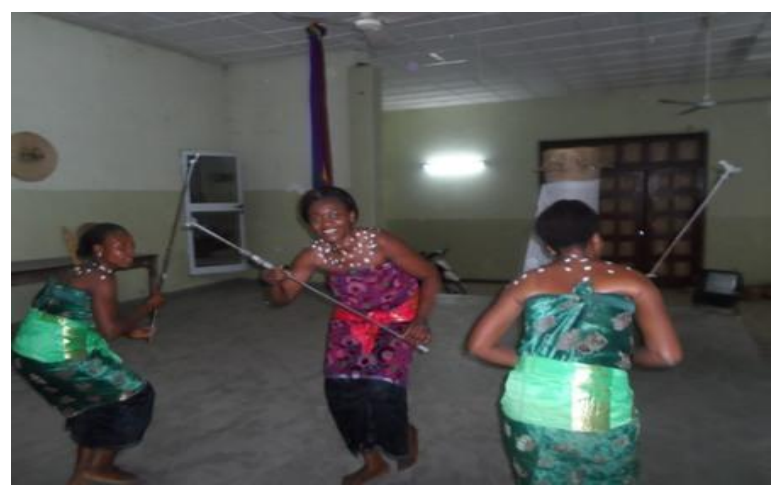

Photo 1: Adjogan dance performed by a group of women in the international house of culture (MIC) of Porto-Novo

Shooting: HOUNGUE Jules, November 2014

It is a princely dance that is only performed on very special occasions. It is found mainly in the courtyard of the royal palace of Porto-Novo. The "Adjogan" is mainly performed during the festivities at the palace by the women of the princely family called "Aîkoungbonsi". They are dressed in "Avallon" black loincloth knotted on the chest and wear different necklaces on the neck. In their hands, we find the "Allohoun", a large metallic object that they handle with mastery. It is a kind of iron rod of about one meter and covered with a copper disc. The princesses while dancing wield the wand and wave in a synchronized movement of the various rings encircling the wand. Nowadays, the "Adjogan" is a dance that is also practiced in the Catholic Church during great celebrations including the feast of Epiphany and weddings.

\section{The djègbé:}

Photo 2 shows a group of man and woman performing the traditional dance steps "djègbé".

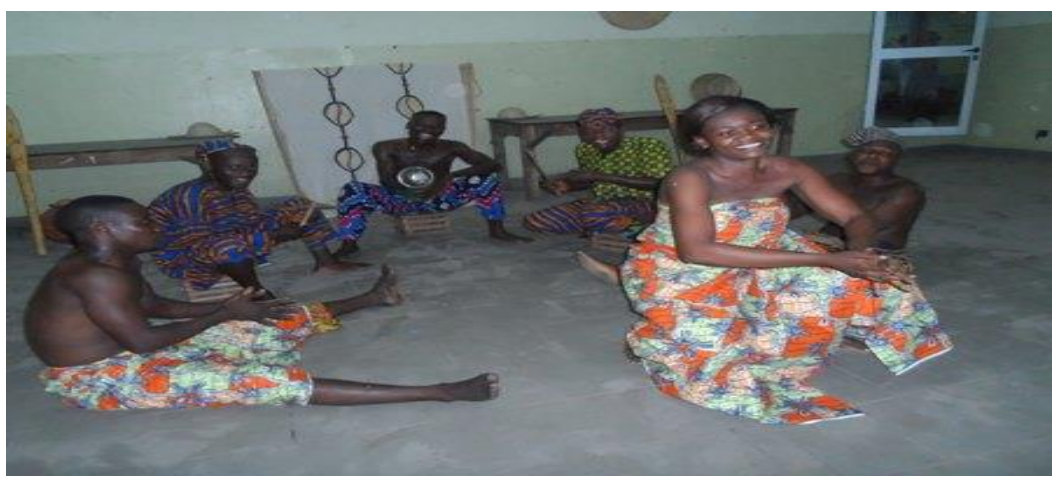

Photo 2: Performance of the Djègbé dance by the student in the international house of culture (MIC) of Porto-Novo 
Shooting: HOUNGUE J., November 2014

This dance is created by old people who perform it under the palaver tree to create the atmosphere of the return from the fields. Men use their hands to tap their often naked torso in a rhythmic fashion to create a fairly dancing rhythm accompanied by the sound of hoe blades.

\section{The Zinlin}

Funeral rhythm born on the Abomey plateau and transported over time to Porto-Novo, the "zinlin" is played with the "Kpezin" that are the main instruments having two forms nuanced by the size: "Kpezinnon" and "Kpezinvi ". We associate them with a drum vase which gave its name to the rhythm: "zinli". All this is accompanied by the sounds of gongs, rattles and clapping of hands supported by songs and dances.

\section{The eyo}

A rhythm of "Sèto", the "Eyo" unlike other very hectic rhythms, gives the dancer pleasure, slow motion and makes those who do not even know how to dance to sketch a few dance steps. Photo 3 shows a group of women performing the traditional " eyo 'dance steps.

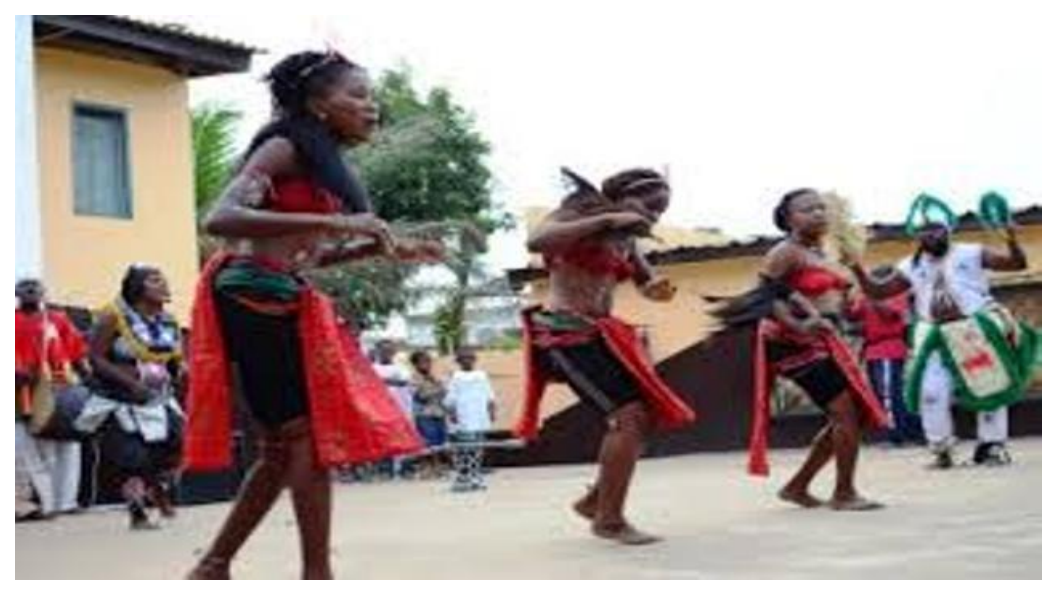

Photo 3: Young girls in full demonstration of the "eyo" dance in the international house of culture (MIC) of Porto-Novo

Shooting: HOUNGUE J., November 2014

The percussion is composed of two (02) "klé", one "agomè", one "akpéssi" and one "dougba" without forgetting the gon and the castanets.

The sato:

Photo 4 shows a group of women performing the traditional dance steps " 'sato' ", 


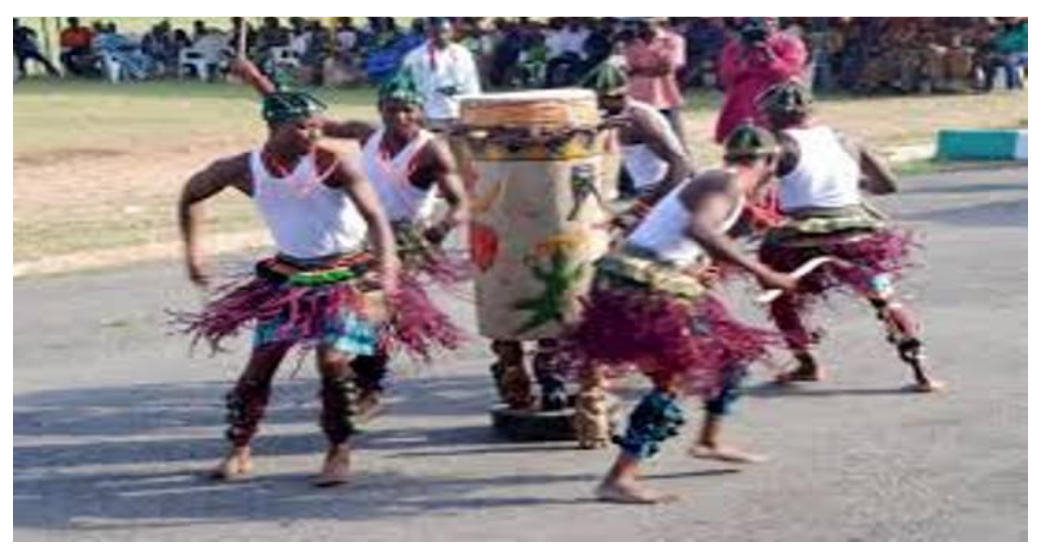

Photo 4: Execution of the Sato rhythm in the garden of plants and nature of Porto-Novo Shooting: HOUNGUE J., November 2014

The "sato" is a ritual which is practiced during the funeral of a king, a dignitary or an important personality of a community.

\section{The kpanouhoun}

"Kpanouhoun" is a dance inspired by scenes from everyday life: eating, quarreling, having fun, working and taking the time to savor life. It's a particularly lively dance. Photo 5 illustrates a group of women performing the traditional dance steps "kpanouhoun".

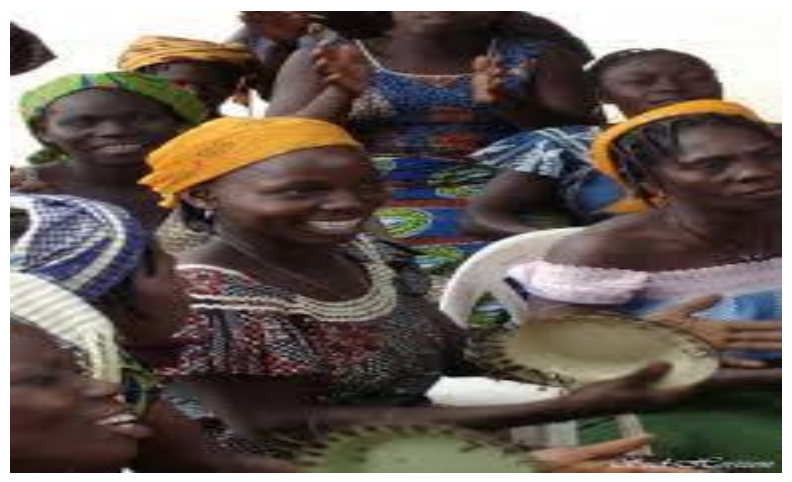

Photo 5: Performing the Kpanouhoun dance in the Akogbéto house in Porto-Novo

Shooting: AKOGBETO N., November 2014

This music, generally performed by women, owes its name to the fundamental element used in its playing. It is indeed a product imported from the West: the enamel dish commonly called "Kpanou". To make this a musical instrument, holes are drilled around it, into which metal rings are inserted.

\section{Le Massè-Gohoun:}


"Gohoun", which had been a rhythm of rivalry between localities for ages, ended up inspiring the illustrious disappeared singer-composer YédénouAdjahoui of his time. He thus added to the gohoun instruments a large case called "AGBA" and then removed the tom-tam "Akohoun" and there was born the "Massè-" Gohoun "which is the pride of the Hogbonoutos today. Photo 6 illustrates a group of men and women performing the traditional dance steps "Massè-Gohoun".

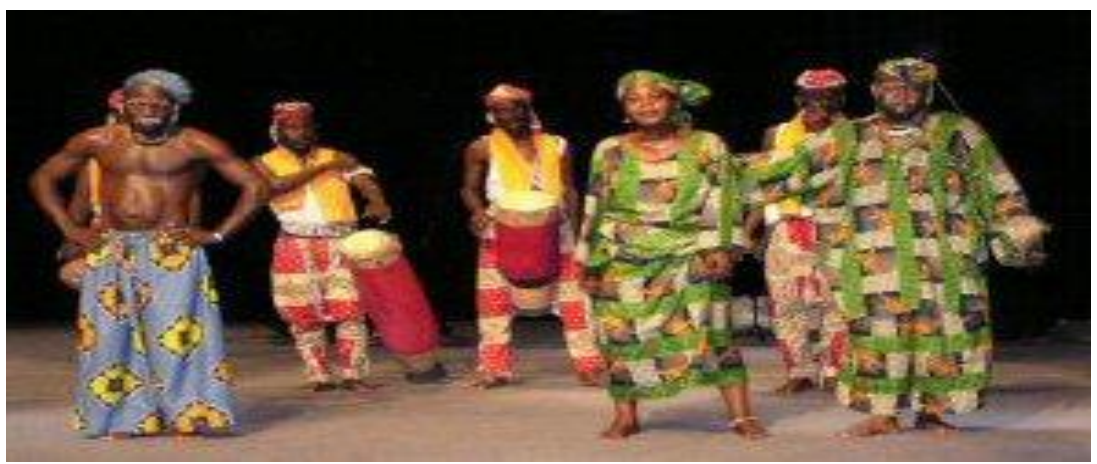

Photo 6: Performing the Massè-Gohoun dance in the international house of culture (MIC) of Porto-Novo

Shooting: HOUNGUE J., November 2014

The "Massè-gohoun" is then played with the tam-tams like: "alè" "and" klé "," agomè "," dougba ", the 02 bells, a castanet and of course the" agba "which makes the difference This rhythm is the best danced and the most loved of the "Hogbonoutos" (the Grand Porto-Novo).

\section{The kaka:}

Created by the inhabitants of Ekpè in the commune of Sèmè-kpodji, this rhythm was immediately adopted by the "Hogbonouto" because of the atmosphere that it produced. "Kaka" is played today during funerals, various festive and recreational activities. Photo 7 illustrates a group of a woman and a group of men performing the traditional dance steps of "kaka".

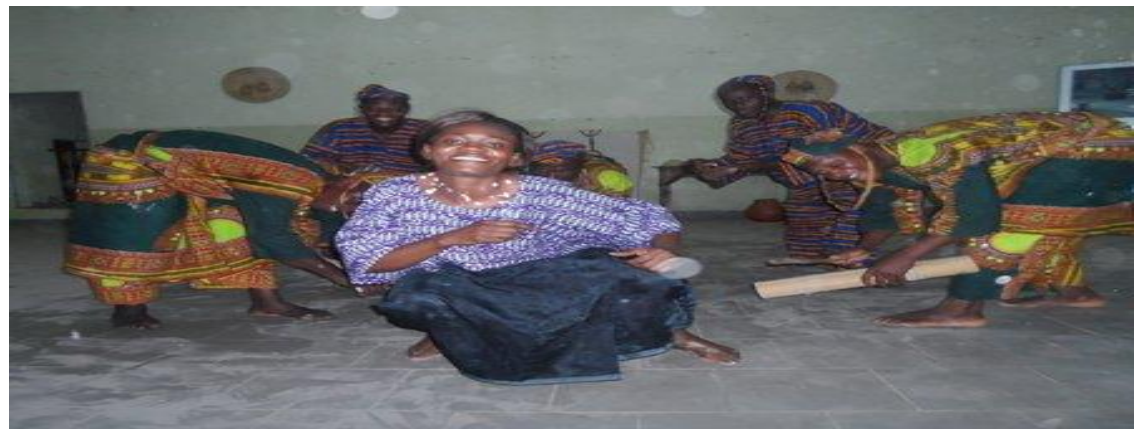

Photo 7: Performing the Kakadans dance at the International House of Culture (MIC) in PortoNovo

Shooting: HOUNGUE J., November 2014 
The "kaka" is both a dance of rejoicing and a ritual dance of the zangbéto. This dance is performed with pieces of bamboo that are tapped against each other to get the rhythm; the dancer is also the player of the musical instrument.

\section{The "ogbon"}

It is dance resulting from the dance "bata" come from Nigeria at the time of the first entry of "egun gun" in Benin and more precisely in Porto-Novo. Photo 8 illustrates a group of men and women performing the traditional de 'ogbon' 'dance steps.

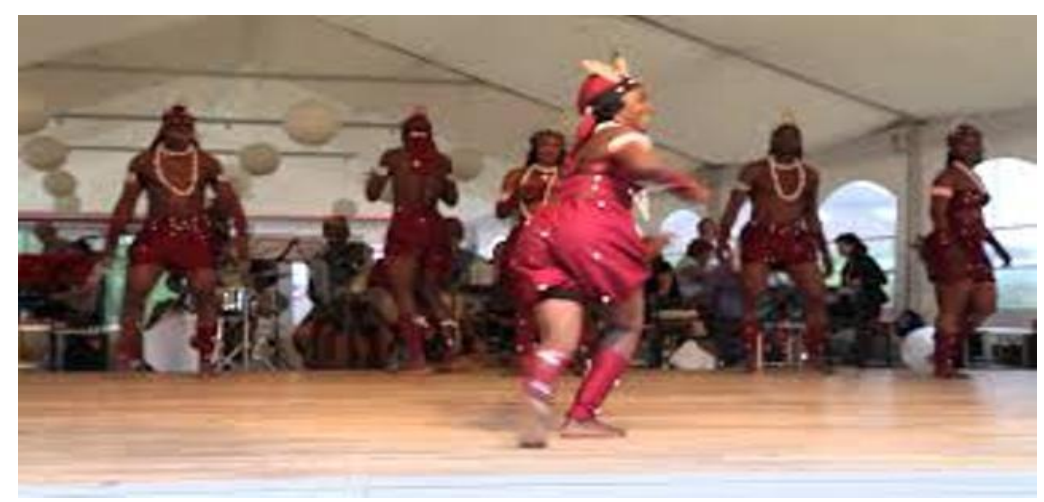

Photo 8: Performing the Ogbon dance at the da-Silva museum

Shooting: AKOGBETO N., November 2014

Originally, the "egun gun" of Nigeria danced the "bata". It is performed by crossing the feet accompanied by movements of the hands forming semicircles.

3.1.2- The deities practicing the traditional dances of the city of Porto-Novo

\section{The "zangbéto"}

Photo 9 illustrates masks "zangbéto" performing traditional dance steps "kaka".

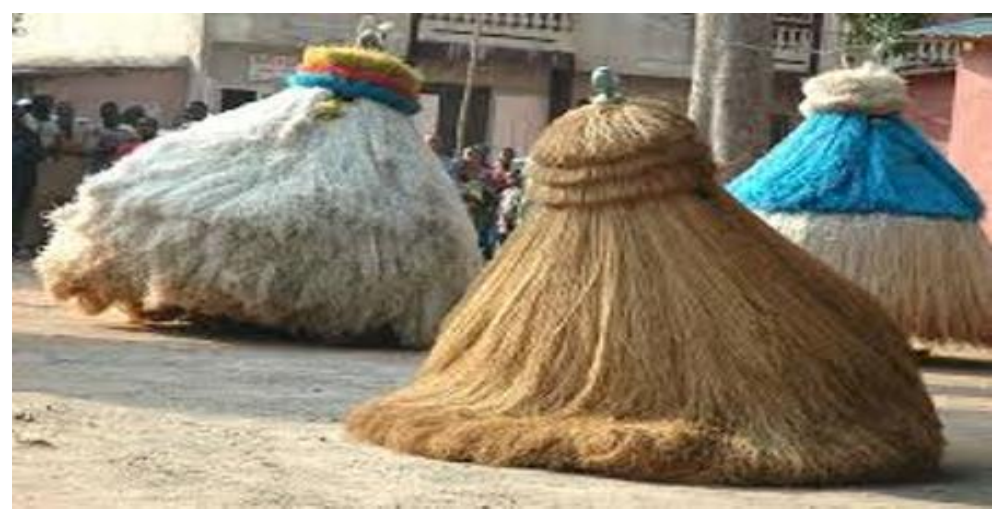

Photo 9: Performance of the Kaka dance by the Zangbétodans in the Akron district 
Shooting: AKOGBETO N., November 2014

Established by King TêAgbanlin founder of the city of Porto-Novo in the 18th century in order to protect the population from thieves, evil spirits and sorcerers, the "Zangbéto" or "guardian of property and people" are in a way a police force by night. He practices Kaka

\section{The "Egun-gun"}

Egun-gun or the mask of the resurrection is a cult of Yoruba origin dedicated to the deceased. It is reserved for men, assisted by an elderly woman with extraordinary powers. She is the embodiment of Iya-Igbalè, the wife of Shango who is a former deified king of Oyo. Photo 10 illustrates an Egun-gun performing the traditional dance steps " 'Ogbon' '.

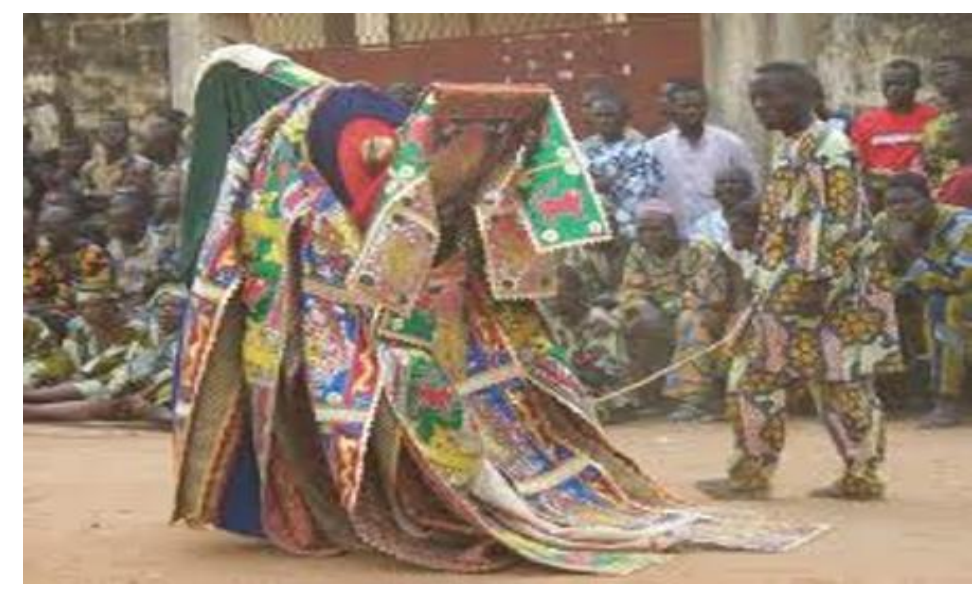

Photo 10: Performance of the Ogbon dance by the Egun-gundans in the Attakè district

Shooting: AKOGBETO N., November 2014

It symbolizes the link between the gods and the ancestors. His son "Egun", born after eight stillborn children, gives his name to the cult which serves as a means of communication between the dead and the living. These masks must be beautiful to give an impression of prosperity, they are made of cotton fabrics, raffia, to which we add materials such as leather, wood, and metal. He practices Ogbon.

\subsection{Tourism and traditional dances in Porto-Novo}

Tourists visiting Benin and the capital of Benin are encountered in several places. Figure 3 shows the margin of tourist meeting places in Porto-Novo 


\section{International Journal of Agriculture, Environment and Bioresearch}

Vol. 5, No. 01; 2020

ISSN: $2456-8643$

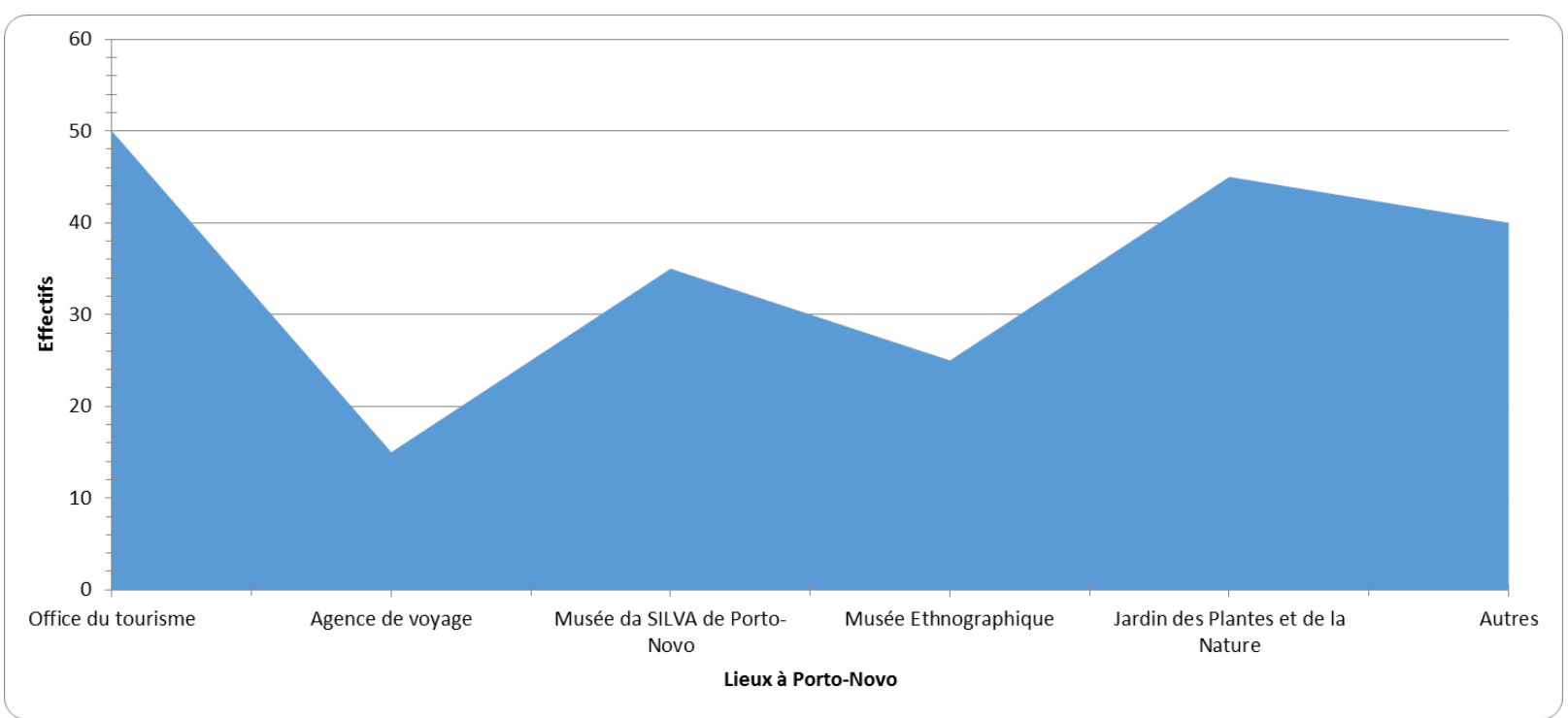

Figure 3: Tourist meeting places

Source: Field survey, December 2014

Analysis of this figure makes it possible to determine the places most frequented by tourists once in Porto-Novo. Thus the places most visited by tourists are: the Tourist Office, the JPN, the others (tourist sites, restaurants, hotels) the da-SILVA museum and the least visited: the Alexandre Senou ADANDE museum, the agency trip.

This analysis makes it clear that despite the plethora of intangible cultural heritage in the capital, tourists are hardly ever encountered at these cultural events due to a lack of communication. Indeed, according to the investigations, tourists come to discover some groups of traditional dancers, are flabbergasted and once back home, usually invite them for shows.

In conclusion, the city of Porto-Novo does not really benefit from the existence of these groups because nothing is organized around to attract more tourists and finally trigger tourism development in the city of Porto-Novo.

\subsection{Valuable activities of traditional dances in the city of Porto-Novo}

Figure 4 takes stock of the activities that can encourage the development of traditional dances in Porto-Novo. 


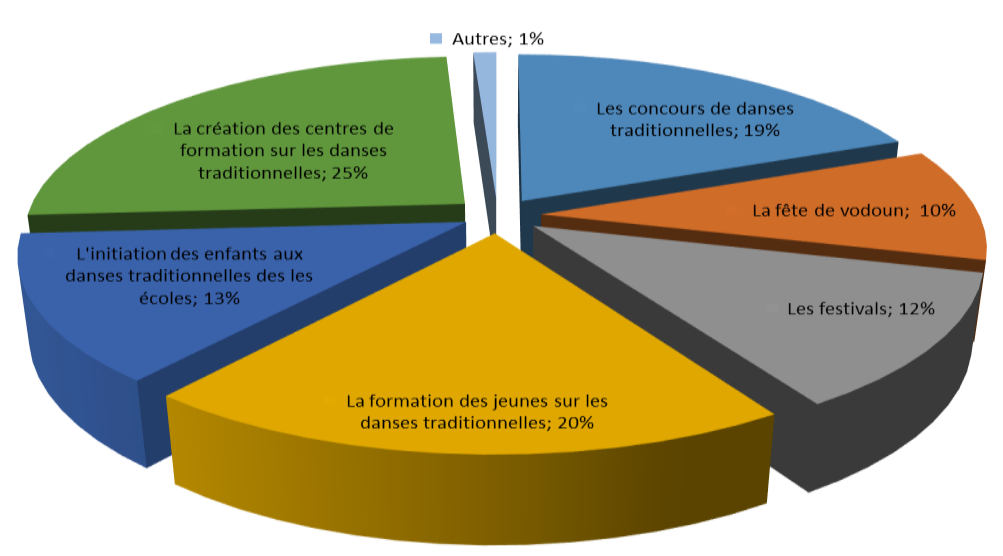

Figure 4: Cultural activities that can promote the development of traditional dances in PortoNovo

Source: Field survey, December 2014

Analysis of the figure shows that all activities, apart from other unidentified activities (1\%), can contribute to the development of traditional dances in Porto-Novo.

We note that 15 to $17 \%$ of those surveyed find that these activities can promote the development of dances in Porto-Novo. For the development of traditional dances in Porto-Novo, the related activities The traditional dance competitions, The feast of vodoun, The festivals, The training of young people on traditional dances, The initiation of children to traditional school dances and creation training centers on traditional dances must therefore be promoted.

\section{CONCLUSION}

In Benin, traditional dances are as numerous and varied as there are regions and ethnic groups throughout the territory of Benin. Each of them has its specificity characterized by its own body language and rhythm. They are above all the expression of emotions, freedom and joie de vivre. They are performed to transmit a tradition, perform a ritual, honor a deity or celebrate an event. These traditional Benin dance rhythms are disappearing in each of its departments.

Ancient city and colonial city, Porto-Novo is the fruit of a national cultural mix and a mixture of peoples (Adja from Togo and Yoruba from Nigeria). One of its main tourist attractions is its rich historical, architectural and cultural heritage. The traditional dances identical to the city of PortoNovo (the Adjogan, the Kaka, the Massè-Gohoun, the Djègbé, and the Ogbon) constitute a rich intangible cultural heritage essential for the city, enhancement projects with strong cultural impacts should be set up to attract more tourists to the city and promote the tourism sector of the city of Porto-Novo.

Dance, a major component of Culture, rests on the circle, a symbol of life both spiritual and temporal. It must benefit from state support, be the engine of projects with socio-cultural impacts. 
Vol. 5, No. 01; 2020

ISSN: $2456-8643$

At the end of this study, it is urgent to act to improve the situation in order to allow the city of Porto-Novo to know its own tourist development and this is valid for all the other municipalities of Benin. There is a need for concerted action by municipal and state authorities. Finally, future studies will focus on the economic impact of promoting traditional dances on the city of PortoNovo.

\section{REFERENCES}

- AKOGBETO N. B. (2016): Traditional dances and local development of the city of PortoNovo, Master thesis, MIRD, FLASH-UAC, 80 pages.

- AMORE A. C., (2014): Tourism potential and development of the Ifangni commune (Southeast of Benin). Master thesis in geography, UAC / FLASH / DGAT, Benin, 97 pages.

- DEKOUNHON C. N. B. (2016): Ecotourism development of the TDS host village of Avlékété (Municipality of Ouidah), License thesis, UCAO, Cotonou 67 pages.

- ELEGBE A. (2001): tourism in the departments of Ouémé and Plateau: Diagnosis and promotion strategy. Master's thesis ; regional planning DGAT, Abomey-Calavi, benin; 100pages.

GANTHEIL J. L. (2002): tourism at the service of local development in bio contact $n{ }^{\circ} 110$, pp. $47-49$

- KABO SI- OUEME. (2007): Guide to cultural and cultural tourist circuits in the greater Ouémé region and other localities in Benin, 23pages.

- MCAT / DPPT (2007): Discover Benin, Cotonou, Benin, 26 pages.

- MEHOU-LOKO V. (1976): tourism in developing countries: myths, realities and perspectives. Talence, France, 17 pages.

UNWTO (2004): Tourism and poverty reduction: Recommendation for action, Madrid, Spain, 55 pages

UNWTO (2011): 1.8 billion international tourists are expected in 2030, Press release. PR NO: PR 11079.

PRINCIPAUD J-P., (2001): international tourism in Benin: a rapidly expanding activity. In Overseas Notebooks Article No. 226-227. April-September 2004. Accessed July 21, 2016 at 9:22

TCHAOU HODONOU C. (2001) the face of Benin from the editions of the flamboyant Cotonou-Bénin 350 pages.

VELLAS F. (2004): sustainable tourism development and poverty reduction Cotonou-Bénin, 510 pages. 